\title{
STRATEGI MENINGKATKAN MINAT MASYARAKAT MENJADI MUZAKKI MELALUI FILANTROPI ISLAM
}

\author{
Khodijah Ishak ${ }^{1}$, Lukman Hakim ${ }^{2}$, Rizki Audina Putri ${ }^{3}$, Mahfud $^{4}$ \& Dita Nur Fatila \\ ${ }_{1,2,3,4 \& 5}$ Sekolah Tinggi Ilmu Ekonomi Syariah Bengkalis \\ Email: khodijahishak2@gmail.com,lukman_hakim94@ymail.com,stiesyariahbks@gmail.com
}

\begin{abstract}
ABSTRAK
Strategi lembaga UPZ dalam memaksimalkan jumlah wajib zakat yang ada di Desa Bukit Kerikil dengan mayoritas penduduknya adalah Muslim. Metode Penelitian yang digunakan adalah metode deskriptif kualitatif. Analsis SWOT yang digunakan adalah metode analisis deskriptif, matrik SWOT dan analisis diagram SWOT. Teknik Pengumpulan data melalui wawancara, kuesioner, observasi dan dokumentasi. Hasil penelitian peneliti memfokuskan pada analisis SWOT sebagai strategi dalam peningkatan minat masyarakat untuk menjadi muzakki di UPZ Miftahul Jannah. Pelaksanaan strategi yang dilakukan untuk peningkatan wajib zakat masih dikatakan belum maksimal. Selama ini strategi yang dilakukan UPZ Miftahul Jannah hanya menggunakan sosialisasi, tanpa didorong dengan menggunakan media cetak, media sosial maupun lainnya, dan faktor penghambatnya masih kurangnya kesadaran masyarakat untuk wajib zakat, dan memilih memberikan langsung kepada mustahiq dan selain itu juga dipicu pada pelayanan yang belum maksimal dan kurang terlihatnya keefektifitas kerja pegawai.
\end{abstract}

Kata kunci : SWOT, Minat Masyarakat, Muzakki, Filantropi Islam.

\begin{abstract}
The strategy of the UPZ institution in maximizing the number of obligatory zakat in Bukit Kerikil Village where the majority of the population is Muslim. The research method used is a qualitative descriptive method. The SWOT analysis used is descriptive analysis method, SWOT matrix and SWOT diagram analysis. Data collection techniques through interviews, questionnaires, observation and documentation. The results of the research researchers focused on SWOT analysis as a strategy in increasing public interest in becoming muzakki at UPZ Miftahul Jannah. The implementation of the strategy carried out to increase the mandatory zakat is still said to be not optimal. So far, the strategy carried out by UPZ Miftahul Jannah has only used socialization, without being encouraged to use print media, social media or others, and the inhibiting factor is the lack of public awareness of obligatory zakat, and choosing to give directly to mustahiq and besides that it is also triggered by services that have not maximum efficiency and less visible employee work effectiveness.
\end{abstract}

Keywords: SWOT, Public Interest, Muzakki, Islamic Philanthropy. 


\section{PENDAHULUAN}

Lembaga filantrofi merupakan lembaga yang membantu masyarakat dalam mengelola zakat untuk disalurkan kepada pihak yang berhak menerima zakat. Lembaga filantrofi pada dasarnya lembaga yang secara sukarela demi kesejahteraan masyarakat (Abidin, 2012). Secara umum Filantropi didefinisikan sebagai tindakan sukarela untuk kepentingan publik. Filantropi merupakan salah satu pendekatan untuk mempromosikan kesejahteraan termasuk didalamnya upaya mengentaskan kemiskinan. Filantropi sebagai salah satu modal sosial melalui pemberian derma atau bantuan kepada masyarakat yang kurang mampu. Tumbuh kembangnya gerakan filantropi salah satunya dengan hadirnya lembaga filantropi Islam berbentuk zakat, infak, dan shadaqah.

Zakat merupakan kewajiban setiap umat Islam dalam menjalankan ibadahnya. Di Indonesia hingga dewasa ini, pengelolaan zakat tidak menjadi bagian dari keuangan negara. Sementara itu, zakat memiliki potensi yang besar untuk meningkatkan kesejahteraan masyarakat (Alam, 2018). Potensi zakat di Indonesia cukup besar. Menurut data Pusat Kajian Strategis Badan Amil Zakat Nasional (BAZNAS) potensi zakat nasional mencapai 217 Triliun pertahun. Sedangkan jumlah dana zakat yang berhasil dihimpun oleh Badan Amil Zakat Nasional dari keseluruhan Unit Pengelola Zakat di Indonesia hanya mencapai 6 Triliun Artinya, dibandingkan dengan potensi zakat yang sangat besar jumlah pengumpulan zakat yang dikumpulkan oleh BAZNAS kurang lebih $1 \%$ per tahun (Pertiwi \& Ghofur, 2020).

Melihat data Badan Zakat Nasional bahwa potensi zakat tahun 2019, berdasarkan IIPZ asosiasi dan pandangan zakat Indonesia, potensi zakat sekitar Rp. 233,8 triliun dibagi menjadi 5 objek Zakat. Pada tahun 2016 dan 2017, pendapatan zakat hanya sekitar 6 triliun. Besarnya potensi zakat di Indonesia membuat semua pelaku zakat atau badan pengumpul zakat harus mencari cara untuk memaksimalkan potensi zakat dan mampu menciptakan kemiskinan di Indonesia (Hidayat \& Mukhlisin, 2020). Desa bukit kerikil adalah salah satu desa yang berada di Kecamatan Bandar Laksamana Kabupaten Bengkalis Provinsi Riau. Wilayahnya mencakup daratan bagian Timur Pulau Sumatera dan wilayah kepulauan. Merupakan kabupaten dengan penduduk Muslim terbesar mencapai 82,03\% dari total masyarakat yang ada di kabupaten Bengkalis. Dapat dipastikan dengan jumlah penduduk Muslim terbesar, Bengkalis juga memiliki potensi zakat yang besar.

Menurut data BAZNAS, potensi pengumpulan zakat di UPZ Miftahul Jannah Desa Bukit Kerikil Kabupaten Bengkalis sebesar 350.942.500, dengan demikian perbandingan antara potensi dan realisasi terdapat gap yang cukup besar mengartikan bahwa pengumpulan dana zakat masih dikatakan kurang optimal.

Tabel 1. Jumlah Muzakki dan Perolehan Dana Zakat UPZ Miftahul Jannah Desa Bukit Kerikil Kabupaten Bengkalis Tahun 2017-2019

\begin{tabular}{ccc}
\hline Tahun & Jumlah Muzakki & \multicolumn{1}{c}{$\begin{array}{c}\text { Jumlah Dana yang } \\
\text { dihimpun }\end{array}$} \\
\hline $\mathbf{2 0 1 7}$ & 83 orang & Rp. 133.129 .500 \\
$\mathbf{2 0 1 8}$ & 35 orang & Rp. 129.654 .000 \\
$\mathbf{2 0 1 9}$ & 10 orang & Rp. 88.159 .000 \\
\hline \multicolumn{2}{c}{ Sumber: UPZ Miftahul Jannah Desa Bukit Kerikil (2020) }
\end{tabular}

Berdasarkan Tabel 1. dapat dilihat bahwa penghimpunan dana zakat besarnya potensi tersebut pada kenyataannya belum dapat terealisasi secara optimal. penghimpunan tersebut bahkan masih terbilang kecil jika dibandingkan dengan potensi penghimpunan zakat.

Jika dikelola dengan baik, zakat dapat berperan besar dalam pembangunan 
ini. Setidaknya, ada empat peran yang dapat dilakukan oleh zakat dalam pembangunan ini, yaitu: (1) memoderasi kesenjangan sosial; (2) membangkitkan ekonomi kerakyatan; (3) mendorong munculnya model terobosan dalam pengentasan kemiskinan; dan (4) mengembangkan sumber pendanaan pembangunan kesejahteraan umat di luar APBN maupun APBD (Aminudin \& Hadidiningrum, 2019).

Pengolahan zakat berdasarkan pada Undang-undang nomor 23 tahun 2011 tentang pengelolaan zakat dengan keputusan Menteri Agama nomor 581 tahun 1999 tentang pelaksanaan undang-undang nomor 23 tahun 2011. Pada hakikatnya berzakat bukan hanya bermanfaat bagi para mustahiq tetapi bermanfaat juga bagi muzakki. Orang yang mengeluarkan zakat (Muzakki) berarti ia telah mensucikan diri, jiwa dan hartanya. Ia telah membersihkan dirinya dari sifat penyakit kikir (bakhil) dan membersihkan hartanya dari hak orang lain yang ada dalam hartanya (Ayuningtyas \& Sari, 2020). Hal ini diperkuat dengan Peraturan Daerah Kabupaten Bengkalis No 3 Tahun 2018 mengamanahkan bahwa dalam rangkan mengoptimalkan pengumpulan zakat BAZNAS Kabupaten dan LAZ dapat menyebarkan programnya melalui iklan dengan mencantumkan nomor rekening pembayaran dana zakat dan lain-lain (Sulistyandari, 2020). Salah satu persoalan yang dihadapi UPZ Miftahul Jannah Desa Bukit Kerikil Kabupaten Bengkalis adalah belum optimalnya dana zakat yang masuk ke UPZ dibandingkan potensi yang ada. Untuk meningkatkan jumlah zakat di UPZ Miftahul Jannah tersebut maka perlu adanya strategi.

Menurut hasil penelitian Nusantara (2010) pendapatan, pengalaman bersedekah dan nilai-nilai religius berpengaruh secara signifikan terhadap kesejehateraan muzakki yang diproksi melalui pengeluaran konsumsi bersedekah, sedangkan umur, status perkawinan, etnis, pendidikan dan kesehatan tidak berpengaruh secara signifikan. Dari ketiga faktor tersebut, pendapatan adalah faktor utama yang mempengaruhi kesejahteraan muzakki yang diproksi melalui pengeluaran konsumsi sedekah. Sedangkan berbeda menurut hasil penelitian Ardiansyuri (2016) yang menyatakan bahwa status perkawinan, pendidikan, pendapatan dan nilai-nilai religius berpengaruh terhadap pengeluaran zakat. Jika melihat dari hasil penelitian diatas dapat disimpulkan bahwa nilai-nilai religius dan pendapatan lebih dominan berpengaruh terhadap seseorang mengeluarkan zakat (muzakki).

Penilaian muzakki terhadap lembaga amil zakat begitu beragam, sesuai dengan persepsi dan pengalaman masing-masing muzakki tidak hanya karakteristik individu, nilai-nilai religius dan pendapatan para muzakki saja melainkan kualitas pelayanan. Pelayanan yang baik yang diberikan oleh lembaga amil zakat kepada muzakki akan berdampak positif kepada tingkat kepercayaan muzakki kepada lembaga amil zakat, sehingga kesadaran membayar zakat akan terus bertambah.

Menurut (Pertiwi \& Ghofur, 2020) faktor penyebab tidak signifakannya realisasi zakat dengan potensi zakat yang ada yaitu, pertama, masih rendahnya pemahaman dan kesadaran umat Islam tentang kewajiban membayar zakat. Kedua, rendahnya minat masyarakat untuk menyetorkan zakatnya kepada institusi pemerintah dan pengelola zakat, dikarenakan banyak sekali lembaga amil zakat yang belum sepenuhnya transparansi atau terkadang tidak memberikan informasi yang jelas kegunaan zakat yang mereka bayar, sehingga para muzakki lebih senang membayar zakatnya langsung ke para mustahiq atau yang berhak. Penghimpunan dana zakat saat ini jauh di bawah potensi besarnya di Indonesia, yang menunjukkan masih rendahnya minat masyarakat untuk berzakat. Untuk meningkatkan minat tersebut, organisasi pengelola zakat menciptakan berbagai inovasi dalam pengelolaan zakat.

\section{TINJAUAN PUSTAKA}

\section{Strategi meningkatkan Minat Masyarakat}

Menurut Muklisin (2018) yang menyatakan bahwa "strategi" merupakan tindakan yang bersifat incremental (senantiasa meningkat) dan terus menerus, 
serta dilakukan berdasarkan sudut pandang tentang apa yang yang diharapkan oleh para pelanggan dimasa depan. Dengan demikian, strategi selalu dimulai dari apa yang terjadi dan bukan dimulai dari apa yang terjadi. Terjadinya kecepatan inovasi pasar yang baru dan perubahan pola konsumen memerlukan kompetensi inti (core competencies). Perusahaan perlu mencari kompetensi inti didalam bisnis yang dilakukan.

\section{Menurut Mudrikah (2018) minat Masyarakat merupakan kesukaan (kecendrungan hati) kepada sesuatu proses yang tetap untuk memperhatikan dan memfokuskan diri pada sesuatu yang diminatinya dengan perasaan senang dan rasa puas.}

Proses strategi dapat dibagi dua secara garis besar yaitu:

a. Strategic planning (Perencanaan strategi), yaitu proses ini mencakup dari penentuan tujuan hingga penyusunan strategi sebagaimana yang telah diuraikan.

b. Strategic implementation (Implementasi strategi), yaitu proses ini mencakup yang dijalankan berdasarkan strategi yang dipilih dan juga pengendalian atas implementasi yang dilakukan.

Pengelolaan zakat oleh lembaga pengelola zakat, apalagi yang memiliki kekuatan hukum formal akan memiliki beberapa keuntungan, antara lain untuk menjamin kepastian dan disiplin pembayar zakat, menjaga perasaan rendah diri para mustahiq apabila berhadapan langsung untuk menerima zakat dari para muzakki, mencapai efisien dan efektifitas. Jika zakat diserahkan langsung dari muzakki kepada mustahiq, meskipun secara hukum syari'at adalah sah. Akan tetapi disamping akan terabaikannya hal-hal tersebut, juga hikmah dan fungsi zakat, terutama yang berkaitan dengan kesejahteraan umat akan sulit diwujudkan.

\section{Muzakki}

Muzakki adalah orang yang dikenai kewajiban membayar zakat atas kepemilikan harta yang telah mencapai nisab dan haul. Telah disepakati oleh umat Islam bahwa zakat hanya diwajibkan kepada seorang muslim, merdeka, dewasa yang berakal, yang memiliki kekayaan dalam jumlah tertentu dengan syarat tertentu (Ayuningtiyas $\&$ Sari, 2020).

Untuk membagun sebuah kepercayaan seorang muzakki maka perlu dijalankan serta dilakukan sebagai berikut:

a. Keterbukaan

Kerahasiaan dan kurangnya transparasi dalam menjalankan sesuatu atau mengganggu trust building. Oleh karena itu diperlukan keterbukaan antara kedua belah pihak agar keduanya dapat saling percaya antara satu sama lain.

b. Kompeten

Kompeten adalah kemampuan untuk melaksanakan suatu tugas atau pera dalam membagun pengetahuan dan keterampilan yang didasarkan pada pengalaman dan pembelajaran. Yakni sebagai syarat untuk dianggap mampu oleh masyarakat dalam melaksanakan tugas dibidang pekerjaan tertentu.

c. Integritas

Integritas adalah keselarasan antara niat, pikiran, perkataan dan perbuatan. Dalam prosesnya, berjanji akan melaksanakan tugas secara bersih, transparan, dan prefesional dalam arti akan mengerahkan segala kemampuan dan sumber daya secara optimal untuk memberikan hasil kerja terbaik.

d. Akuntabilitas

Akuntabilitas merupakan dorongan psikologi sosial yang dimiliki seseorang untuk mempertanggungjawabkan sesuatu yang telah dikerjakan kepada ligkungannya atau orang lain.

e. Sharing

Sharing adalah sebuah pengakuan atau pengungkapan dari terhadap orang lain yang berfungsi untuk berbagai sesuatu untuk meringankan sebuah masalah. Sharing merupakan elemen penting 
dalam membangun kepercayaan Karena mempunyai manfaat nilai psikologi yakni membantu membangun yang lebih baik antara satu sama lain.

\section{f. Penghargaan}

Untuk mendorong sebuah kepercayaan maka harus terdapat respek saling menghargai antara satu sama lain. Karena didalam sebuah lembaga di perlukan rasa kepercayaan muzakki terhadap suatu lembaga zakat dalam mengandalkan lembaga untuk menyalurkan zakatnya kepada mustahiq zakat, karena lembaga dianggap amanah, jujur, transparan, dan professional.

\section{Filantropi dalam Islam}

Filantropi yang diwujudkan oleh masyarakat Isalam awal sampai sekarang dalam berbagai bentuk, seperti zakat, infak, shadaqah, dan wakaf. Kegiatan filantropi ini dikembangkan dengan berdirinya lembagalembaga yang mengelola sumber daya yang berasal dari kegitan filantropi yang didasarkan dalam perintah yang ada dalam Al-Quran dan Hadist. Lembaga ini semakin berkembang karena perannya dalam upaya mengurangi kesenjangan sosial (ekonomi) dalam masyarakat (Tamin, 2011).

\section{METODE PENELITIAN}

Sumber data yang dikumpulkan dari penelitian ini terdiri dari data Primer dengan melakukan wawancara serta data sekunder yaitu, laporan-laporan perkembangan dana UPZ Miftahul Jannah Desa Bukit Kerikil Kecamatan Bandar Laksamana. Dalam menganalisis data penelitian ini menggunakan cara pengumpulan data dan kemudian dibandingkan dengan teori yang ada (Trianto, 2016).

Penelitian ini menggunakan analisis SWOT berdasarkan konsep David. Tujuan dari analisis tersebut adalah untuk mengkaji strategi yang dilakukan UPZ dalam meningkatkan jumlah Muzakki. Analisis SWOT berarti analisis berdasarkan pada Strengths, Weakness, Opportunities dan Threaths yakni kekuatan, kelemahan, kesempatan, kendala. Melalui analisis SWOT, akan membantu dalam penyimpulan akhir penelitian. Analisis SWOT menggunakan matriks Internal Factor Evaluation (IFE) dan matriks Eksternal Factor Evaluation (EFE). Dimana IFE yang meliputi kekuatan diantaranya sosialisasi dan tempat yang strategis sedangkan kelemahan meliputi kurangnya kesadaran masyarakat akan wajib zakat, Pelayanan yang belum memuaskan, Fasilitas dan insfrastruktur masih kurang memadai, kurangnya tingkat pengetahuan dan keahlian tenaga kerja serta sosialisasi yang belum maksimal. Sedangkan EFE meliputi peluang adanya perlindungan pemerintah berupa Undang-undang dan Inpres, kemudian kerjasama masyarakat. Sedangkan yang menjadi ancaman adalah tidak stabilnya donatur atau muzakki.

Peneliti hanya terfokus pada strategi UPZ dalam meningkatkan jumlah muzakki dari tahun 2017-2019, sehingga dapat tergambar secara utuh bagaimana kesimpulannya. Peneliti melakukan wawancara kepada pihak Pengumpul Zakat Miftahul Jannah Desa Bukit Kerikil Kecamatan Bandar Laksamana mengenai kondisi lingkungan objek penelitian yang mendukung kegiatan penelitian serta dialog lisan antara peneliti dengan ketua UPZ, dan masyarakat Desa Bukit Kerikil.

\section{HASIL PENELITIAN DAN PEMBAHASAN}

Berdasarkan hasil wawancara yang dilakukan Bersama pihak UPZ Miftahul Jannah Desa Bukit Kerikil Kecamatan Bandar Laksamana, dalam meningkatkan jumlah muzakki strategi yang digunakan oleh UPZ Miftahul Jannah yaitu:

a. Maintenance donator (service exxelence)

Yaitu pelayanan kepada donator, berupa jemput zakat.

\section{b. Foundrising based on community}

Yaitu strategi dengan langkah-langkah komunitas. Komunitas yang dibidik adalah perkantoran, majelis taklim, sekolah, pengusaha. 


\section{c. Foundrising based on program}

Yaitu strategi dengan mengenalkan berbagai program yang ada di UPZ Miftahul Jannah dalam mencari donatur dan calon donatur sehingga donatur mempunyai keinginan untuk menyalurkan dana zakatnya melalui UPZ Miftahul Jannah.

Berdasarkan dari keterangan diatas maka UPZ Miftahul Jannah melakukan strategi, strategi yang digunakan saat melakukan sosialisasi memberikan motivasi kepada masyarakat untuk berzakat yaitu:

a. Mengadakan musyawarah maupun perkumpulan kecil bertemakan meningkatkan minat masyarakat untuk menjadi muzakki. Para muzakki menyadari begitu pentingnya berzakat dengan menambah pengetahuan masyarakat tentang zakat itu sendiri.

b. Mengadakan seminar di kantor desa maupun mengadakan perkumpulan kecil di organisasi lain dengan narasumbernya yang berasal dari salah satu bagian pengumpulan maupun pengelolaan zakat Desa Bukit Kerikil. Konsep ini diperkuat oleh penelitian yang dilakukan oleh (Mashuri \& Nurjannah, 2020).

c. Mengisi acara-acara berupa ceramahceramah dimajelis taklim maupun acara peringatan hari-hari besar Islam.

Dengan strategi tersebut UPZ Miftahul Jannah mendapatkan kepercayaan dari para muzakkinya. Selain itu terbukanya pengelolaan UPZ Miftahul Jannah dengan transparannya dalam pengelolaan dananya dan adanya hubungan kerjasama menjadi kepercayaan tersendiri bagi muzakki untuk menyalurkan zakatnya. Dengan berbagai starategi yang digunakan UPZ Miftahul Jannah seharusnya jumlah muzakki dan dana zakat dapat mencapai target yang telah ditentukan. Namun dalam pencapaiannya jumlah muzakki dan jumlah perolehan dana zakat yang diperoleh masih tergolong kecil. Hal ini dapat dilihat dari tabel 2. tahun terakhir data muzakki di UPZ Miftahul Jannah dibawah ini :

Tabel 2. Jumlah Muzakki dan Perolehan Dana Zakat UPZ Miftahul Jannah Desa Bukit Kerikil Kabupaten Bengkalis Tahun 2017-2019

\begin{tabular}{lllll}
\hline Tahun & Jumlah penduduk & Jumlah muzakki & $\begin{array}{l}\text { Jumlah dana } \\
\text { dihimpun }\end{array}$ & yang \\
\hline $\mathbf{2 0 1 7}$ & 1.300 jiwa & 83 orang & Rp 133.129.500 & \\
$\mathbf{2 0 1 8}$ & 1.300 jiwa & 35 orang & Rp 129.654.000 & \\
$\mathbf{2 0 1 9}$ & 1.300 jiwa & 10 orang & Rp 88.159 .000 & \\
\hline
\end{tabular}

Sumber: UPZ Miftahul Jannah Desa Bukit Kerikil (2020)

Ditahun 2017 dana zakat yang terkumpul cukup besar. Pada tahun 2018 mengalami penurunan yang diakibatkan kurangnya kesadaran masyarakat akan wajib zakat dan sebagian dari masyarakatnya lebih memilih memberikan zakatnya langsung pada mustahiq. Pada tahun 2019 kembali mengalami penurunan dengan jumlah yang cukup besar yang diakibatkan dengan masalah yang sama yaitu kurangnya kesadaran masyarakat akan wajib zakat.
Apabila pengelolaan zakat dilakukan dengan baik dan benar maka zakat bisa menjadi sumber dana tetap yang cukup potensial untuk menunjang suksesnya pembangunan nasional, terutama dalam bidang agama dan ekonomi (Hubeis \& Najib, 2014).

Adapun hasil dari Faktor Analysis Summary (IFAS) dan Eksternal Faktor Analysis Summary (EFAS) untuk menentukan strategi dalam meningkatkan jumlah Muzakki. 
2021, Jurnal Tabarru' : Islamic Banking and Finance 4 (2) : 551 - 561

Tabel 3. Internal Faktor Analysis Summary (IFAS)

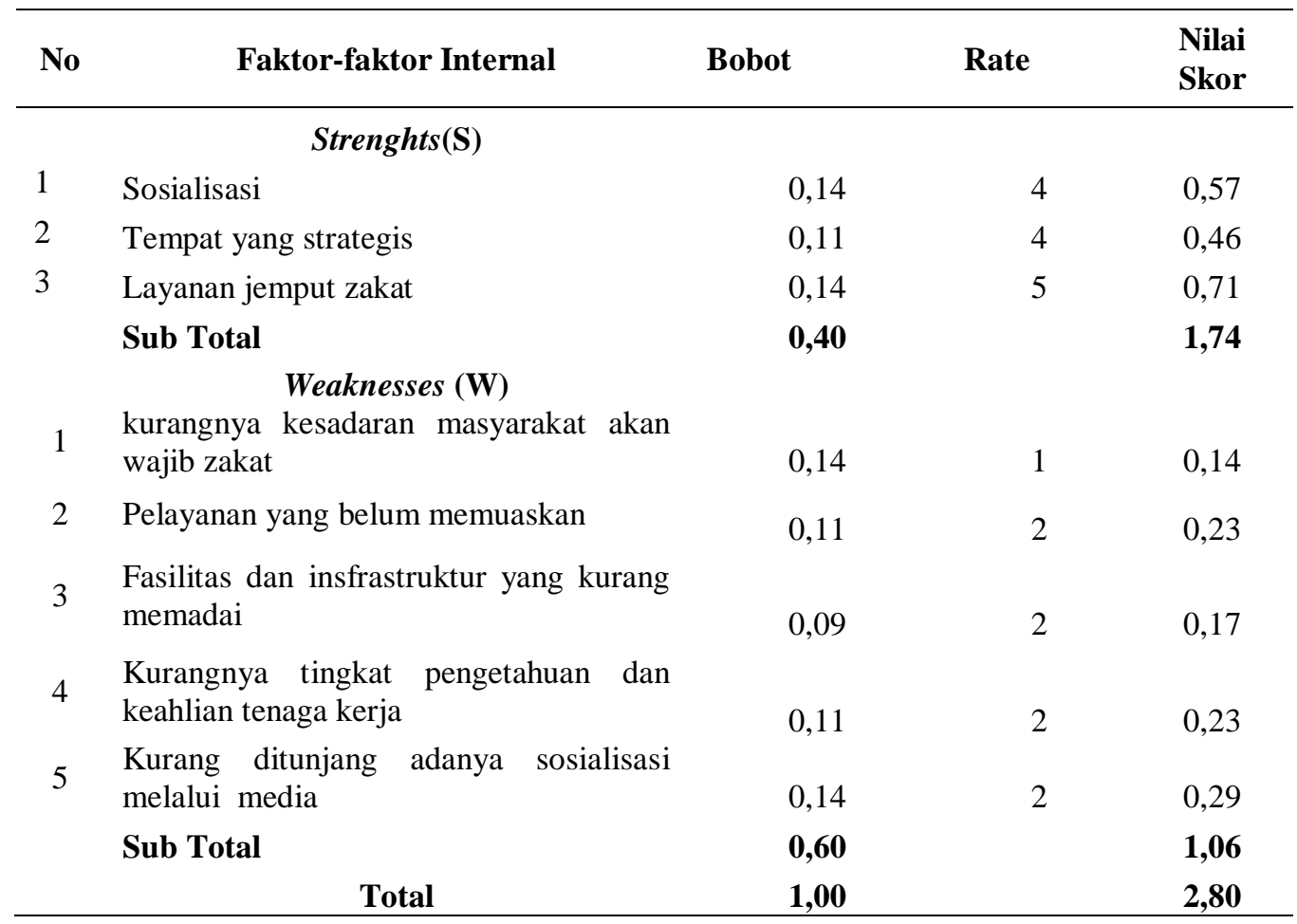

Sumber : Data Olahan (2021)

Pada tabel 3. diatas faktor-faktor kekuatan (Strengths) mempunyai nilai skor 1,74, sedangkan faktor-faktor kelemahan (weaknesses) mempunyai nilai skor 1,06. Berarti dalam peningkatan minat masyarakat untuk menjadi muzakki di UPZ Miftahul Jannah mempunyai kekuatan yang lebih tinggi dibandingkan dengan faktor kelemahan dalam menentukan strateginya. Artinya, Strategi yang dilakukan UPZ sudah tepat dalam mengatasi kelemahan yang dimiliki.

Adapun hasil dari Eksternal Faktor Analysis Summary (EFAS) dalam penelitian ini adalah :

Tabel 4. Eksternal Faktor Analysis Summary (EFAS)

\begin{tabular}{|c|c|c|c|c|c|}
\hline No & Faktor-Faktor Eksternal & Bobot & Rate & & $\begin{array}{l}\text { Silai } \\
\text { kor }\end{array}$ \\
\hline & Opportunities $(\mathrm{O})$ & & & & \\
\hline 1 & Kerja sama dengan masyarakat & 0,29 & & 4 & 1,14 \\
\hline 2 & $\begin{array}{l}\text { Adanya perlindungan pemerintah dengan dikeluarkan } \\
\text { peraturan UU No23 Tahun } 2011 \text { tentang pengelolaan } \\
\text { zakat }\end{array}$ & 0,36 & & 4 & 1,43 \\
\hline \multirow{5}{*}{1} & Sub Total & 0,64 & & & 2,57 \\
\hline & Threats (T) & & & & \\
\hline & Tidak stabilnya donatur atau muzakki & 0,36 & & 1 & 0,36 \\
\hline & Sub Total & 0,36 & & & 0,36 \\
\hline & Total & 1,00 & & & 2,93 \\
\hline
\end{tabular}

Sumber : Data Olahan (2021) 
Pada tabel 4. diatas faktor-faktor peluang (opportunities) mempunyai nilai skor 2,57 dan faktor ancaman (threats) mempunyai nilai skor 0,36 ini berarti dalam upaya menentukan strategi dalam peningkatan minat masyarakat untuk menjadi muzakki di UPZ Miftahul Jannah Desa Bukit Kerikil mempunyai peluang cukup besar dibandingkan ancaman yang timbul.

Dari hasil susunan faktor-faktor internal dan eksternal diatas, menghasilkan rangkaian skor sebagai berikut : Kekuatan (strengths $/ S) \quad=\quad 1,74, \quad$ Kelemahan (weaknesses $/ W) \quad=\quad 1,06, \quad$ Peluang $($ opportunities $/ O)=2,57$ dan Ancaman $($ threats $/ \mathrm{T})=0,36$.

Tabel 5. Rekap Skor IFAS dan EFAS

\begin{tabular}{ccc}
\hline Skor Internal & Skor Eksternal & Pilihan Strategi \\
\hline $\mathrm{S}>\mathrm{W}(+)$ & $\mathrm{O}>\mathrm{T}(+)$ & Growth \\
$\mathrm{S}>\mathrm{W}(+)$ & $\mathrm{O}<\mathrm{T}(-)$ & Diversifikasi \\
$\mathrm{S}<\mathrm{W}(-)$ & $\mathrm{O}>\mathrm{T}(+)$ & Turn-arround \\
$\mathrm{S}<\mathrm{W}(-)$ & $\mathrm{O}<\mathrm{T}(-)$ & Difensif \\
\hline
\end{tabular}

Tabel 6. Matriks SWOT

\begin{tabular}{|c|c|c|}
\hline IFAS & Strengths (Kekuatan) & Weaknesses (Kelemahan) \\
\hline & $\begin{array}{l}\text { 1. Sosialisasi } \\
\text { 2. Tempat yang strategis }\end{array}$ & $\begin{array}{l}\text { 1. Kurangnya kesadaran } \\
\text { masyarakat akan wajib zakat. } \\
\text { 2. Pelayanan yang belum } \\
\text { memuaskan. } \\
\text { 3. Fasilitas dan insfrastruktur } \\
\text { masih kurang memadai. } \\
\text { 4. Kurangnya tingkat pengetahuan } \\
\text { dan keahlian tenaga kerja. } \\
\text { 5. Pengelola kurang memberikan } \\
\text { sosialisasi, kurang ditunjang } \\
\text { adanya sosialisasi melalui } \\
\text { media. }\end{array}$ \\
\hline Opportunities (Peluand) & SO & WO \\
\hline 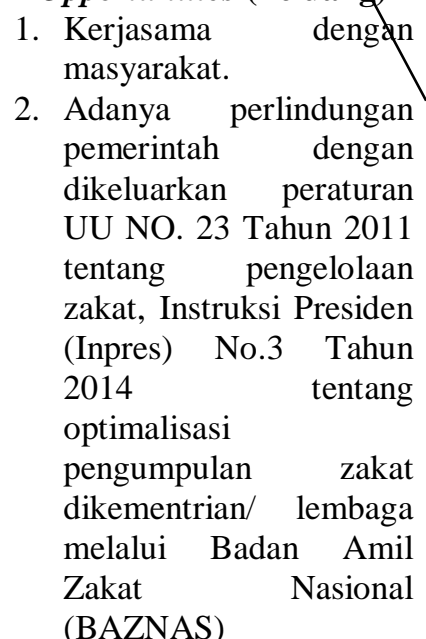 & $\begin{array}{l}\text { 1. Pihak UPZ Miftahul Jannah } \\
\text { harus mampu meningkatkan } \\
\text { minat masyarakat untuk } \\
\text { berzakat, bukan hanya dalam } \\
\text { bersosialisasi namun juga di } \\
\text { tunjang dengan adanya media } \\
\text { lain. }\end{array}$ & $\begin{array}{l}\text { 1. Meningkatkan komunikasi serta } \\
\text { pendekatan pihak UPZ Miftahul } \\
\text { Jannah kepada masyarakat. } \\
\text { 2. Pihak UPZ Miftahul Jannah } \\
\text { memberikan soft skill berupa } \\
\text { pelatihan kepada karyawan yang } \\
\text { baru direkrut. } \\
\text { 3. Pihak UPZ Miftahul Jannah } \\
\text { memasang instrument alat } \\
\text { komunikasi berupa plang/baliho } \\
\text { sebagai pendorong minat } \\
\text { masyarakat untuk berzakat. }\end{array}$ \\
\hline
\end{tabular}




\section{$\begin{array}{lll}\text { Treaths (Ancaman) } & \text { ST } & \text { WT }\end{array}$}

1. Tidak stabilnya donatur 1. Mempunyai surat izin didirikan atau muzakki.

UPZ Miftahul Jannah di Desa Bukit Kerikil dari BAZNAS Bengkalis.

2. Pihak UPZ Miftahul Jannah harus mampu mempertahankan donatur atau muzakki yang sudah menjadi bagian UPZ Miftahul Jannah.
1. Memperbaiki pengelolaan dalam kinerja kearah yang lebih baik.

2. Memperhatikan kualitas mutu pelayanan terhadap muzakki.

3. Memperbaiki sarana dan prasarana yang ada seperti memasang wifi, serta penambahan perangkat pada kantor UPZ Miftahul Jannah.

4. Memanfaatkan media sosial, sebagai media promosi.
Strategi ini dibuat berdasarkan jalan pikiran perusahaan, yaitu dengan memanfaatkan seluruh kekuatan untuk merebut dan memanfaatkan peluang sebesarbesarnya.

Pihak UPZ Miftahul Jannah harus mampu meningkatkan minat masyarakat untuk berzakat, bukan hanya dalam bersosialisasi namun juga di tunjang dengan adanya media lain.

\section{Strategi ST (Strengths Treaths)}

Adalah strategi dalam menggunakan kekuatan yang dimiliki perusahaan untuk mengatasi ancaman.

a. Mempunyai surat izin didirikan UPZ Miftahul Jannah di Desa Bukit Kerikil dari BAZNAS Bengkalis.

b. Pihak UPZ Miftahul Jannah harus mampu mempertahankan donatur atau muzakki yang sudah menjadi bagian UPZ Miftahul Jannah.

\section{Strategi WO Opportunities)}

(Weaknesses

Strategi ini diterapkan berdasarkan pemanfaatan peluang yang ada dengan cara meminimalkan kelemahan yang ada.

a. Meningkatkan komunikasi serta pendekatan pihak UPZ Miftahul Jannah kepada masyarakat.

b. Pihak UPZ Miftahul Jannah memberikan soft skill berupa pelatihan kepada karyawan yang baru direkrut.

c. Pihak UPZ Miftahul Jannah memasang instrument alat komunikasi berupa plang/baliho sebagai pendorong minat masyarakat untuk berzakat.

\section{Strategi WT (Weaknesses Treaths)}

Strategi ini didasarkan pada kegiatan yang bersifat defensif dan berusaha meminimalkan kelemahan yang ada serta serta menghindari ancaman Mudrikah (2018).

a. Memperbaiki pengelolaan dalam kinerja kearah yang lebih baik.

b. Memperhatikan kualitas mutu pelayanan terhadap muzakki.

c. Memperbaiki sarana dan prasarana yang ada seperti memasang wifi, serta penambahan perangkat pada kantor UPZ Miftahul Jannah.

d. Memanfaatkan media sosial, sebagai media promosi.

Pendekatan filantropi Islam yang bertujuan untuk mensejahterakan masyarakat sudah hampir terwujud, meskipun masih ada beberapa masyarakat kurang mampu yang tidak mendapatkan bantuan. Tetapi bagi sebagian masyarakat yang merasakan dampaknya merasa sangat beruntung dan terbantu dengan adanya lembaga filanropi tersebut. Dengan proses pengelolaan dana bantuan yang dikelola langsung oleh pihak lembaga dan juga penyaluran yang juga dilakukan langsung oleh pihak lembaga tanpa melalui perantara.

Ada beberapa bentuk bantuan yang lembaga berikan untuk masyarakat, ada bantuan dalam bentuk konsumtif yang merupakan bantuan dalam bentuk pangan, seperti beras bahan makanan dan juga 
sedekah untuk memenuhi kebutuhan hidup sehari-hari yang cukup dalam jangka pendek. Selain itu lembaga juga memberikan bantuan berupa bantuan produktif yang merupakan bantuan dalam bentuk modal usaha. Bantuan produktif ini diberikan kepada masyarakat yang baru akan memulai usaha maupun yang ingin mengembangkan usahanya tetapi memiliki keterbatasan modal.

\section{KESIMPULAN}

Strategi yang dilakukan di UPZ Miftahul Jannah untuk menarik minat masyarakat melalui pendekatan lembaga filantropi tidak efektif. selama ini Strategi hanya difokuskan melalui sosialisasi saja, tidak didukung dengan adanya media lain, seperti baliho maupun media cetak, media sosial, dan lainnya. Setelah dilakukan evaluasi terhadap strategi yang dilakukan saat ini dengan menggunakan sosialisasi dianggap kurang tepat, dikarenakan masyarakat lebih cenderung pada sosial media untuk mendapatkan informasi dengan cepat. Dari hasil analisis SWOT pihak UPZ hendaknya menambah kuantitas strategi selain mengandalkan strategi yang telah ditetapkan.

\section{DAFTAR PUSTAKA}

Abidin, Zaenal. 2012. Manifestasi dan Latensi Lembaga Filantropi Islam dalam Praktik Pemberdayaan Masyarakat, Suatu Studi di Rumah Zakat Kota Malang. Jurnal Studi Masyarakat Islam (SALAM), 15(2), p. 197-214.

Alam, Ahmad. 2018. Permasalahan dan solusi pengelolaan zakat di Indonesia. Jurnal Manajemen, 9(12), p. 134135.

Aminudin, Muhammad Zumar., \& Hadidiningrum, Lila Pangestu. 2019. Pengelolaan ZIS Dalam Upaya Meningkatkan Kesejahteraan Masyarakat Dan Penanggulangan Kemiskinan. Jurnal Zakat Dan Wakaf (ZISWAF), 6(01), p. 80-100.
Ardiansyuri. 2016. Analisis Pengaruh Pengeluaran Zakat, Infak Dan Sedekah Terhadap Kesejahteraan Muzakki (Studi Pada Baznas Di Kabupaten Lombok Barat). International Journal of Social and Local Economic Governance (IJLEG), 2(1), p. 23-31.

Ayuningtyas, Rosida Dwi., \& Sari, Risti Lia. 2020. Analisis Minat Muzakki Membayar Zakat Di Badan Amil Zakat Nasional (Baznas) Kota Semarang. AKSES : Jurnal Ekonomi dan Bisnis, 15(1), p. 45-54.

Hidayat, Andi., \& Mukhlisin. 2020. Analisis Pertumbuhan Zakat Pada Aplikasi Zakat Online Dompet Dhuafa. Jurnal Ilmiah Ekonomi Islam, 6(03), p. 675684.

Hubeis, Musa., \& Najib, Mukhamd. 2014.

$\begin{array}{lrr}\text { Manajemen Strategik } & \text { dalam } \\ \text { Pengembangan } \quad \text { Daya } & \text { Saing } \\ \text { Organisasi. PT. Elex } & \text { Media } \\ \text { Komputindo. Jakarta. } & \end{array}$

Mashuri., \& Nurjannah, Dewi. 2020. Analisis SWOT Strategi Meningkatkan Daya Saing (Studi pada PT. Bank Riau Kepri Unit Usaha Syariah Pekanbaru). JPS : Jurnal Perbankan Syariah, 1(1), p. 97-112.

Mudrikah. 2018. Manajemen Strategi Peningkatan Minat Masyarakat Untuk Menjadi Muzakki Di LAZISMU Banyumas. Skripsi Program Studi Manajemen Dakwah Jurusan Pengembagan Masyarakat Fakultas Dakwah Institut Agama Islam Negeri. Purwokerto.

Muklisin. 2018. Strategi Pengelolaan Zakat dalam Upaya Pengembangan Usaha Produktif (Studi Kasus Pada 
2021, Jurnal Tabarru' : Islamic Banking and Finance 4 (1) : 551 - 561

BAZNAS Kabupaten Bungo). Jurnal

Ilmiah Syariah, 17(2), p. 205-214.

Nusantara. 2010. Analisis Kesejahateraan Muzakki Berdasarkan Pengeluaran Konsumsi Sedekah (Studi di Kota Malang Provinsi Jawa Timur). Disertasi, Universitas Brawijaya.

Pertiwi, Intan Suri Mahardika., \& Ghofur, Ruslan Abdul. 2020. Optimalisasi Potensi Zakat : Faktor Yang Mempengaruhi Muzzaki Membayar Zakat Di Baznas Lampung Tengah. Jurnal Niara, 13(2), p. 1-10.

Sulistyandari. 2020. Strategi Peningkatan Pertumbuhan Dana Zakat Pada Badan Amil Zakat Nasional Kabupaten Bengkalis. Jurnal Tabarru' : Islamic Banking and Finance, 3(2), p. 347-359.

Tamin, Imron Hadi. 2011. Peran Filantrofi dalam Pegentasan Kemiskinan Didalam Kominitas Lokal. Jurnal Sosiologi Islam, 1(1), p. 35-58.

Trianto, Budi. 2016. Riset Modeling. Adh Dhuha Institut . Pekanbaru. 